\title{
The Draft Protocol on the Creation of the Court of Justice of Mercosur. A New Milestone
} in the Judicialisation of Regional Integration Law

\section{El proyecto de protocolo relativo a la creación de un Tribunal de Justicia del Mercosur. Un hito en la judicialización del derecho de integración regional}

\section{Werner Miguel Kühn Baca*}

SUmmary: I. Introduction. II. Mercosur's current dispute settlement mechanism. III. TheWay Ahead. IV. Bibliography.

* Doctorado en Derecho por la Universidad de Kiel (Alemania); especialización en Derecho de la Comunidad Andina, del Mercosur, de la Unión Europea y del Espacio Económico Europeo. Ejerció de 2004 a 2012 la función de letrado en gabinetes de Abogados Generales en el Tribunal de Justicia de la Unión Europea en Luxemburgo. Trabaja desde 2013 como funcionario jurídico en el Directorado Mercado Interior de la Autoridad de Vigilancia de la Asociación Europea de Libre Comercio (“EFTA Surveillance Authority”) en Bruselas. 
RESUMEN: El presente artículo contiene un análisis detallado del proyecto de protocolo relativo a la creación de un Tribunal de Justicia del Mercosur. El análisis enfoca diversos aspectos de tipo institucional y procesal, al mismo tiempo que sitúa el proyecto de protocolo en el contexto general del derecho de la integración supranacional actual. El objetivo es demostrar que dicho proyecto de protocolo es el resultado de un sofisticado trabajo de derecho comparado que incorpora valiosos aportes basados en la experiencia adquirida en los procesos de integración iniciados en Europa y Latinoamérica. A fin de explicar mejor de dónde provienen y en qué consisten esos aportes, el análisis hace referencia a la reglamentación existente en los demás sistemas de integración, en particular, la Comunidad Andina, el Sistema de Integración Centroamericano, la Unión Europea, la Asociación Europea de Libre Comercio y la recientemente creada Unión Económica Euroasiática.

Palabras clave: derecho procesal supranacional, integración económica regional, derecho comparado, tribunales internacionales.

ABSTRACT: The present article contains a detailed analysis of the draft protocol on the creation of a court of justice of Mercosur. The analysis focuses on several institutional as well as procedural aspects, while putting the draft protocol in the general context of current supranational law. The objective is to demonstrate that the draft protocol must be regarded as the result of a sophisticated work of comparative law, which incorporates valuable legal contributions based on the experience gained in integration processes launched both in Europe and Latin America. In order to better explain where these legal contributions originate from, what they consist in, as well as to describe the current stage of evolution of regional economic integration in its supranational format, the analysis refers to the rules in force in the other integration systems, more specifically, the Andean Community, the Central American Integration System, the European Free Trade Association and the recently established Eurasian Economic Union.

Key words: supranational procedural law, regional economic integration, comparative law, international courts.

RÉSUMÉ: Le présent article contient une analyse détaillée du projet de protocole relatif à l'établissement d'une Cour de Justice du Mercosur. L'analyse est centrée sur des divers aspects de caractère institutionnel et procédural, tout en plaçant le projet de protocole dans le contexte général du droit de l'intégration supranational actuel. L'objectif consiste à démontrer que ledit projet de protocole constitue le résultat d'un travail de droit comparé sophistiqué incorporant des apports précieux basés sur l'expérience acquise dans les processus d'intégration lancés en Europe et Amérique Latine. Afin de mieux expliquer d'où et en quoi consistent ces apports, l'analyse fait référence au règlement existant dans les autres systèmes d'intégration, notamment la Communauté Andine, le Système d'Intégration de l'Amérique Centrale, l'Union Européenne, l'Association Européenne de Libre Échange et la récemment créée Union Économique Eurasiatique.

Mots-clés: droit de procédure supranational, intégration économique régionale, droit comparé, tribunaux internationaux. 
Esta revista forma parte del acervo de la Biblioteca Jurídica Virtual del Instituto de Investigaciones Jurídicas de la UNAM

\section{INTRODUCTION}

Five years have passed since Parlasur submitted a draft protocol to the Member States of Mercosur for approval, envisaging the creation of a permanent Court of Justice for this South American integration system. Repeated calls for reform of Mercosur's dispute settlement mechanism have remained unheard ever since, as the national governments' focus of attention has shifted to the economic and political difficulties this regional integration system has had to face. The recent election of a new government in Argentina has raised hopes that the reform would be finally implemented. This article will explain the necessity of this reform. It will further provide an account of the key features of the draft protocol, which intends to remedy the shortcomings of the current dispute settlement mechanism, while highlighting the influence that European and Latin American integration law has had. The conclusion to be drawn is that the draft protocol constitutes a milestone in the judicialisation of regional integration law and that a failure to make it legally binding would have to be considered a missed opportunity for regional economic integration.

In December 2010, after an intense debate, Parlasur - the parliamentary assembly of Mercosur - expressed its support for the establishment of a Court of Justice for Mercosur. The authors of the draft protocol creating the necessary legal basis were deputies Alfonso Rodríguez Sáa (Argentina) and Eric Salum Pires (Paraguay). After the adoption of the resolution approving it, the draft protocol was submitted to the Consejo del Mercado Común $(« \mathrm{CMC})$ - the supreme political body of Mercosur - for deliberation, ${ }^{1}$ which, to date, has failed to scrutinise it. This is regrettable, given the important innovations the draft protocol introduces to Mercosur's dispute settlement mechanism. Admittedly, Mercosur has had to face more urgent matters, such as the admission of Venezuela as a member and the suspension of Paraguay's membership following the institutional crisis in that country. ${ }^{2}$

1 The draft protocol was handled as dossier MEP 134/09 and submitted to the Comisión de Asuntos Jurídicos e Institucional («CAJI») of Parlasur. After a year of assessment, the draft protocol was submitted to the plenary session of Parlasur for debate, which accepted it as Legislative Proposal 2/10 of 13 December 2010. After the parliamentary approval, the draft protocol was submitted to the CMC on 14 December 2010 for its consideration and final approval.

2 The institutional crisis caused by the impeachment of President Fernando Lugo, the subse- 
In addition, Bolivia's interest in joining the trade bloc despite its membership of the Andean Community ( CAN») remains undiminished. However, after overcoming most of these challenges, the time would appear ripe for a new attempt to adjust the institutional framework to the demands of the integration process.

Before explaining the details of the reform, it appears sensible to describe concisely the current setup of Mercosur's dispute settlement mechanism. A closer look at the deficiencies of this mechanism will make clear why various legal scholars have called for reform. ${ }^{3}$ The draft protocol must be regarded as an initiative aimed at providing a political answer to this appeal for reform.

\section{MERCOSUR's CURRENT DISPUTE SETTLEMENT MECHANISM}

\section{Actions aimed at pursuing infringements}

Article 33 of the UN Charter provides that a dispute settlement mechanism is an important instrument for the peaceful solution of international conflicts, listing a few examples such as negotiation, enquiry, mediation, conciliation, arbitration, judicial settlement, resort to regional agencies or arrangements, or other peaceful means of the parties' choice. The Protocol of Olivos («PO»), put in place the Tribunal Permanente de Revisión («TPR») in Mercosur, which seeks to resolve disputes concerning the interpretation, application and infringement of Mercosur law (which comprises the Treaty of Asunción «TA»: the treaty by which Mercosur was established, its protocols and the agreements concluded, as well as the disputes arising in connection with decisions, resolutions and directives adopted by Mercosur bodies having decision-making competence). Notwithstanding this, the

quent suspension of Paraguay in Mercosur on grounds of an alleged breach of the Protocol of Ushuaia regarding the Commitment of Mercosur to Democracy, and the entry of Venezuela in the organization as a full member led to litigation before the TPR. See, Rey Caro, Ernesto, "Crisis Institucional en el Mercosur. El Laudo No 1/12 del Tribunal Permanente de Revisión”, Revista de la Facultad, 2013, p. 27.

3 Perotti, Alejandro, "El proyecto de creación de la Corte de Justicia del Mercosur: estado de las negociaciones", Foro de Derecho Mercantil, 2009, p. 115. 
Esta revista forma parte del acervo de la Biblioteca Jurídica Virtual del Instituto de Investigaciones Jurídicas de la UNAM

Member States of Mercosur have the right to submit their disagreements to the WTO or any other dispute settlement mechanism.

The origins of the dispute settlement mechanism currently in place in Mercosur go back to the Protocol of Brasilia ( $(\mathrm{PB} »)$, which was replaced by the PO. The PB introduced a dispute settlement mechanism similar to the one that exists in the North American Free Trade Agreement («NAFTA»), ${ }^{4}$ although the PO reshaped it so as to create one resembling more to the mechanism in place in the European Union («EU») and the CAN. Even though the PO creates a more sophisticated mechanism than found in NAFTA, it does not reach the level of sophistication attained by the EU or the CAN, as it does not foresee the establishment of a permanent court of justice but rather of a TPR.

Another important difference is the participation of individuals in the dispute settlement mechanism. There is no possibility under the PO to activate the dispute settlement mechanism directly, an option which exists in both the EU and CAN. The mechanisms in place in these integration systems allow individuals to submit their disputes before a permanent court of justice without the prior intervention of the respective Member State. Articles 39 and 40 PO provide for the right of individuals to lodge complaints before the respective National Section of the Grupo del Mercado Común ( GMC») — the executive body of Mercosur - concerning legislative or administrative measures that allegedly have restrictive effect or are liable to distort competition in breach of Mercosur law. The procedure foresees that the complainants must provide elements of evidence confirming the authenticity of the breach as well as the existence or the threat of damage, so as to allow the complaint to be formally admitted by the National Section and assessed by the GMC and the group of experts summoned for this purpose.

The dispute settlement mechanism of Mercosur consists essentially of the following stages: (i) bilateral negotiations between Member States; (ii) the submission of the dispute to the GMC through consultations and complaints; and (iii) arbitration before the ad hoc panel and the TPR. When a

4 The principal dispute settlement mechanisms of the NAFTA are found in Chapters 11 (Settlement of disputes between a party and an investor of another party), 19 (Mechanism to provide an alternative to judicial review by domestic courts of final determinations in antidumping and countervailing duty cases, with review by independent binational panels), and 20 (Disputes regarding the interpretation or application of the NAFTA). 
dispute arises, the first step is to launch bilateral negotiations. ${ }^{5}$ If no agreement is found, it is possible to opt for the procedure before the Comisión de Comercio ( $(\mathrm{CCM} »)$, which does not preclude the lodging of a complaint before the GMC, which will formulate detailed — but non-binding - recommendations as to how to solve the dispute. Where the settlement of the dispute in the two previous procedural stages has been unsuccessful, any of the Member States involved may inform the Secretaría Administrativa («Secretariat») - the body in charge of providing technical support to the other Mercosur bodies - of its intention to resort to the arbitration procedure (thus starting the third and last stage, which requires the setting up of an ad hoc panel).

Every ad hoc panel is made up of three members. Every Member State involved in the dispute shall designate one panel member respectively, while the third panel member, who chairs the panel and who may not be a national of either of the Member States, shall be designated by common agreement. In the event that no agreement should be found on the choice of the chair, the PO provides that the Secretariat shall designate it on the basis of a list of candidates drawn up for this purpose. The Member States have the right to designate their representatives and legal counsel. As the name suggests, the ad hoc panel is a tribunal expressly created for the resolution of the dispute in question. The panel must therefore limit itself to rule on the subject matter of the dispute, as determined by the written submissions and the pleadings of the parties. The parties must submit their factual and legal observations in support of their respective views.

Article 17 PO provides that any of the Member States involved in the dispute may appeal the panel decision before the TPR within 15 days of the notification of the decision to the parties. The TPR is composed of five referees, designated by each Member State, and a replacing referee, who shall be elected by unanimous vote. The referees must be permanently available. The TPR shall adopt a ruling within 30 days (with a possibility of an extension for another 15 days). The TPR has the power to confirm, modify or revoke the legal reasoning and the decisions adopted by the ad hoc panel. The TPR's arbitral award will be final, overriding the ad hoc panel's decision.

5 This mechanism bears a slight similarity with the dispute settlement mechanism of the Eurasian Economic Union («EurAsEU») in so far as the latter also prescribes a mandatory attempt of pre-trial resolution prior to a referral of the matter to CJ-EurAsEU, according to Article 43 of its Statute. 
It is feasible to skip certain stages of the procedure foreseen by the dispute settlement mechanism, as Article 23 PO provides for the possibility for the parties to submit the dispute immediately and in last instance to the TPR, however, only once the direct negotiations have ended. In this case, the TPR has the same competence as an ad hoc panel, with the consequence that its arbitral awards have the effect of res iudicata. They cannot be subject to revision. The importance of Article $23 \mathrm{PO}$ gives the Member States the option of saving the time usually consumed by the regular dispute settlement mechanism created by the PB and refined by the PO. The regular procedure can last up to 195 days (including the possible extension of deadlines) from the initiation of the direct negotiations. The frequent use of the option laid down in Article 23 PO by the Member States involved might eventually favour turning the TPR into a permanent court of justice. However, for the time being, the Member States have shied away from taking this next, crucial step.

The arbitral awards — of both the ad hoc panels and the TPR — must be adopted by a majority, contain an account of reasons, and be signed by the chair and the other referees. The referees must keep their deliberation and the voting confidential. The parties to the dispute must comply with the arbitral award within the time limits specified. In the event that the Member State party to the dispute should not comply with the arbitral award, the harmed party is allowed to apply countermeasures in order to avoid any damages. Where proof has been adduced of a situation likely to cause grave and irreparable damages, the parties may request interim measures. Before the entry into force of the PO, interim measures could be ordered until the ad hoc panel would adopt its arbitral award. Nowadays, the effect of interim measures cease when the TPR has adopted it arbitral award.

\section{Mechanisms aimed at obtaining an interpretation or verification} of validity of integration law

To a similar extent as other integration systems, ${ }^{6}$ Mercosur has a mechanism in place allowing certain bodies to request an interpretation of the in-

6 Article 267 TFEU in the EU (preliminary rulings); article 34 SCA in the EFTA pillar of the EEA (advisory opinions); article 32 TTJCAN in the CAN (cuestiones prejudiciales); 
Esta revista forma parte del acervo de la Biblioteca Jurídica Virtual del Instituto de Investigaciones Jurídicas de la UNAM

tegration system's common rules. ${ }^{7}$ The $«$ Opiniones Consultivas» are reasoned decisions adopted by the TPR in response to legal questions submitted, concerning the interpretation and application of the Mercosur in an individual case, with a view to safeguard its uniform application in the territory of the Member States. The mechanism is also applicable in circumstances in which it is necessary to verify the validity a specific legal act or provision of integration law. It can be invoked by the Member States acting jointly, the bodies of Mercosur having decision-making powers (CMC, GMC, and CCM), the Supreme Courts of the Member States, and Parlasur.

Secondary Mercosur legislation allows the supreme courts to extend this competence to other supreme judicial bodies of the Member States, ${ }^{8}$ a competence that has not yet been used. Conversely, there is no legal provision in Mercosur law allowing lower national courts to refer questions directly to the TPR without the intermediary of the supreme courts. In other words, lower national courts must submit their questions on interpretation of Mercosur law to their supreme court before a referral to the TPR is possible at all. This is explicitly prescribed by secondary Mercosur legislation, ${ }^{9}$ which requires the adoption of national implementing measures, a task that has been entrusted not to the parliaments but to the supreme courts. ${ }^{10}$ Internal legislation adopted in the meantime by the supreme courts of all Member States specifies that all national courts may initiate a referral, either

Article 22 lit. k Statute CJ-SICA in the SICA (consultas prejudiciales). The Court of Justice of the Eurasian Economic Community ( «CJ-EurAsEC») used to have the competence laid down in Article 3 of the Private Litigants Treaty to give advisory opinions upon request of a national supreme court, even though it was only used once during its existence. The Court of Justice of the Eurasian Economic Union («CJ-EurAsEU») has not been conferred any similar competence (Karliuk, Maksim, "The Eurasian Economic Union: An EU-like legal order in the post-Soviet space?”, WP BRP 53/LAW/2015 National Research University Higher School of Economics, 2016, pp. 15-16; Ispolinov, Alexei, "First judgments of the Court of the Eurasian Economic Community: Reviewing Private Rights in a New Regional Agreement”, Legal Issues of Economic Integration, 2013, 225 (228).

7 Article 9, MERCOSUR/CMC/DEC. N 37/03.

8 MERCOSUR/CMC/DEC. $\mathrm{N}^{\circ} 02 / 07$.

9 MERCOSUR/CMC/DEC. N ${ }^{\circ}$ 02/07 and MERCOSUR/GMC/RES. N N $^{\circ}$ /0/04 and $\mathrm{N}^{\mathrm{o}}$ $41 / 04$.

10 Atela, Vicente/Gajate, Rita/Martínez, Lautaro, "Las retenciones a las exportaciones ante el ordenamiento jurídico del Mercosur. La CSJN va al Tribunal Permanente de Revisión. Análisis desde el Derecho Constitucional, de la Integración y del Internacional Económico”, Anales de la Facultad de Ciencias Jurídicas y Sociales, 2010, 272 (274). 
Esta revista forma parte del acervo de la Biblioteca Jurídica Virtual del Instituto de Investigaciones Jurídicas de la UNAM

at first instance or at appeal level, as well as motu proprio or upon request by any of the parties to the procedure. Request for referrals must originate in judicial procedures before national courts. The manner in which the implementing national legislation has been drafted in all Member States allows the conclusion that the interpretation of the Mercosur law in question must be deemed relevant for the resolution of the dispute. Given the fact that only the supreme courts are allowed to refer questions directly to the TPR, while the role of lower national courts is rather limited to request a referral and to pre-formulate the questions, there is no distinction between facultative and obligatory referrals as is the case in the legal systems of the EU ${ }^{11}$ and the CAN. ${ }^{12}$ The procedure initiated by the national courts is officially considered to be of «judicial cooperation» because it does not require the involvement of the ministries of foreign affairs or any other bodies belonging to the executive branch. The supreme courts' role is to declare whether the request for referrals admissible.

The TPR has a period of 65 days to respond to the questions referred. ${ }^{13}$ The opinion must be based on Mercosur law and can be adopted by a majority of votes. The decision must state any dissenting votes. It is important to note that the opinion is neither binding nor obligatory. ${ }^{14}$ However, it is generally presumed to have a certain de facto authority as it is produced by a highly specialised judicial body. ${ }^{15}$ The national delegations at the GMC may submit written observations within 15 days after the notification of the admissibil-

11 Article 267(3) TFEU. See the terminology used in EU legal theory, Barents, René, Directory of EU Case Law on the Preliminary Ruling Procedure, Alphen aan den Rijn, 2009, p. 112; Noll, Gregor, Negotiating Asylum. The EU Acquis, Extraterritorial Protection and the Common Market of Deflection, The Hague 2000, p. 143; Puntscher, Sonja et al., The State of Europe - Transformations of Statehood from a European Perspective, p. 336; Lepoutre, Naiké, "Le renvoi préjudiciel et l'instauration d'un dialogue des juges. Le cas de la Cour de justice de l'Union européenne et du juge administratif français”, Jurisdoctoria, no. 6, June 2011.

12 Article 33 TTJCAN. See the explanations by the TJCAN on facultative and obligatory referrals, clearly inspired by the case law of the ECJ, in Cases 154-IP-2011, p. 6 and 57-IP2012 , p. 5 .

13 MERCOSUR/CMC/DEC. N ${ }^{\circ}$ 15/10

14 Article 11 MERCOSUR/CMC/DEC. No 37/03.

15 Chediak González, Jorge/Benítez Rodríguez, Pablo, “Acerca de la competencia consultiva del Tribunal Permanente de Revisión del Mercosur y de la experiencia del poder judicial del Uruguay en la tramitación de opiniones consultivas", Revista de la Secretaría del Tribunal Permanente de Revisión, 2014, p. 88. 
Esta revista forma parte del acervo de la Biblioteca Jurídica Virtual del Instituto de Investigaciones Jurídicas de la UNAM

ity of the request of an opinion, with the aim of supporting the TPR in its deliberations. Once the decision has been adopted, the procedure comes to an end, although Mercosur law foresees two scenarios, which go beyond the TPR's scope of competence: the non-presentation of opinions for particular reasons and the beginning of a dispute as the result of an opinion.

\section{Mercosur's long inner struggle over the future of its institutional framework}

Contrary to other integrations systems in the Americas (specifically, the CAN and the Central American Integration System («SICA»)), Mercosur has opted for an intergovernmental model of integration, deliberately rejecting any attempt to infuse elements of supranationality into its legal system. ${ }^{16}$ Consequently, Mercosur has a very lean institutional framework, a trait that becomes particularly evident in the manner in which its dispute settlement mechanism is configured. That mechanism is characterised inter alia by: (1) the instrumentalisation by the State of the individual affected by a breach of Mercosur law in order to pursue infringements by other Member States rather than by bodies safeguarding the integrity of the legal system; (2) the resort to direct negotiations between the Member States; and (3) the use of an arbitration system. The initial belief in the advantages of such a model has given way to serious doubts by legal scholars as to whether the lack of a robust institutional framework will manage to contribute to the further development of the integration process. ${ }^{17}$ An intergovernmental integration model becomes vulnerable when it is obliged to rely exclusively on the goodwill of its Member States, in particular when they have an overly presidential format, as is the case of Argentina and Brazil. This vulnerability is exacerbated by the absence of any mechanisms to reduce asymmetries (in terms of economic and, ultimately, of political power),

16 Rey Caro, Ernesto, "Reforzamiento institucional del Mercosur: ElTribunal Permanente de Revisión”, Anuario Argentino de Derecho Internacional, 2004, p. 194, explains that, at the time of creation of Mercosur, the political will to put in place an authentic judicial body was lacking.

17 Ruíz Díaz Labrano, Roberto, “Mercosur, necesidad de un tribunal de carácter supranacional”, Azpilcueta, 1999, 29; Scotti, Luciana and Klein Vieira, Luciane, "La creación de un tribunal de justicia: Un paso ineludible para el fortalecimiento del Mercosur”, in Scotti, Balances y perspectivas a 20 años de la constitución del Mercosur, 2013, pp. 151-170. 
Esta revista forma parte del acervo de la Biblioteca Jurídica Virtual del Instituto de Investigaciones Jurídicas de la UNAM

relying rather on an unrealistic «formal» equality between the Member States. An integration system, which does not prevent Member States from using economic and/or power as a leverage to enforce their interests, does not inspire confidence in its legal system.

Lack of legal certainty is detrimental to the survival of an integration system in the long run. In order to depoliticise disputes and to strengthen Mercosur's legal system for the benefit of the citizens, the idea of creating a permanent court of justice of Mercosur was proposed by various legal scholars. A major concern was the need to ensure the uniform interpretation and application of Mercosur law. It was feared that leaving it to the national courts to interpret Mercosur law in light of their own legal traditions and using their methodologies would lead to a situation, in which Mercosur law would not have the same validity or effect in each Member State.

It was also argued that the arbitration model appeared to be more appropriate for an association or a cooperation agreement rather than for an ambitious process, the objective of which is to achieve integration at legal, commercial, economic, social, and cultural level. Indeed, Article 1 TA provides that the Member States agree to establish a common market, implying the free movement of goods, services and production factors, the creation of a customs union and the adoption of a common trade policy. It also implies the coordination of macro-economic and sectorial policies in the areas of foreign trade, agriculture, industrial development, taxation, monetary policy and capitals, services, customs, transport, and communication, as well as others to be agreed upon, apart from guaranteeing adequate conditions of competition in the Member States.

Mercosur law was expected to gradually evolve into community law and the arbitration model was considered inadequate, once Mercosur would have moved on from its foundational phase. The very nature of ad hoc panels was regarded as an obstacle to ensuring a uniform case law. The lack of established rules of procedure was deemed to undermine legal certainty, as it could not be ruled out that the ad hoc panels might rule differently in similar disputes. Furthermore, it was argued that even though a mechanism foreseeing negotiation and arbitration might solve individual conflicts, it would not guarantee a uniformity of general resolution criteria applicable to all cases. In addition, the solution of conflicts by consensus and, in the majority of cases, by intergovernmental non-judicial bodies lacking independence and by referees lacking experience appeared insupportable. The establishment 
Esta revista forma parte del acervo de la Biblioteca Jurídica Virtual del Instituto de Investigaciones Jurídicas de la UNAM

of the TPR as a permanent arbitration panel was seen as major step in the institutionalisation of Mercosur, as it reflected the aspiration by the Member States to create a «community of law», with at least a «judicial instance» at its top. It should be noted in this context that various provisions of primary Mercosur law had foreseen the creation of a «permanent dispute settlement mechanism» (although not necessarily a court of justice)..$^{18}$

Apart from the deficiencies of the dispute settlement system described above, the view was taken that the current dispute settlement mechanism failed to guarantee proper access to justice to individuals. In fact, individuals are only allowed to lodge complaints in certain areas, while only Member States have the right to bring disputes before the resolution bodies (as a matter of locus standi). Commentators harboured hope that a future permanent court of justice might help implement such a fundamental right as a right of access to justice.

The conviction grew that a harmonious interpretation of Mercosur law meant the basis of every regional integration process and that it could only be achieved by means of a permanent judicial body bestowed with the competence of interpretation, being the interpretation given binding upon the Member States. ${ }^{19}$ There were doubts concerning the right approach though, as the view was taken by some that the creation of a court of justice would not make sense before Mercosur law had evolved into community law. According to this viewpoint, a judicial dialogue would have to start between the national supreme courts, which would eventually create a body of case law and provide normative content to Mercosur law. According to the opposite view, the creation of a court of justice was an urgent step to take, recalling in this context the European integration experience, which, in their opinion, had been characterised by the creation of strong institutions designed by lawyers, ultimately facilitating economic integration. ${ }^{20}$

18 Annex III No 3 Treaty of Asunción; Article 34 Protocol of Brasilia (repealed); Article 44 Protocol of Ouro Preto; Article 53 Protocol of Olivos.

19 Logar, Ana Cristina, “Tribunal de Justicia para el Mercosur. Una Decisión Impostergable”, Revista de Relaciones Internacionales, no. 12, 1997; Martínez Puñal, Antonio, "El Protocolo de Olivos para la Solución de Controversias en el Mercosur: una reforma en clave continuista", Anuario de Derecho Europeo, no. 3, 2003, pp. 177-198; Gazze, Patricio, "Desarrollo del Derecho ambiental en el ámbito del Mercosur. El desafío a futuro que plantea el caso de las pasteras del Río Uruguay”, El Derecho, no. 66, 2013, p. 6.

20 Klumpp, Marianne, Schiedsgerichtsbarkeit und Ständiges Revisionsgericht des Mercosur, Heidelberg 2013, pp. 406-409. 
Esta revista forma parte del acervo de la Biblioteca Jurídica Virtual del Instituto de Investigaciones Jurídicas de la UNAM

After having described Mercosur's dispute settlement mechanism and highlighted its deficiencies, the following analysis will focus on the major features of the reforms introduced by the draft protocol and explain the manner in which they are intended to address these shortcomings.

\section{Major Aspects of the Dispute Settlement Mechanism Introduced by the Draft Protocol}

\section{A. Procedure Required for its Enactment}

Contrary to the situation in the EU and to what its character as parliamentary assembly might suggest, Parlasur is a consultative body of Mercosur without any legislative powers. ${ }^{21}$ Its competence in connection with the draft protocol is therefore limited to submitting it to the CMC for political approval in accordance with Article 4(13) of the Constitutive Protocol of the Mercosur Parliament. For the protocol to become legally binding, the Member States represented in the CMC would have to incorporate it into the legal order of Mercosur by approving it in accordance with their respective national constitutional requirements. ${ }^{22}$ In order for the future judicial body to become operational immediately and without restraints, the simultaneous entry into force of the draft protocol would have to be ensured. For that purpose, the implementation procedure laid down in Article 40 PO would have to be used, which foresees that, once the Mercosur legal act has been adopted, the Member States must proceed to adopt the necessary national implementing measures. Once this has occurred, they must notify it to the Secretariat, which will inform all Member States. Ar-

21 Article 24TA provides for the creation of a «Joint Parliamentary Commission» however, without specifying its competences. These are set out in detail in Article 4 of the Constitutive

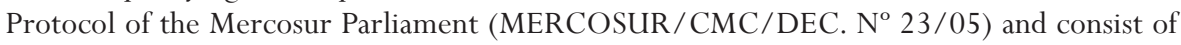
surveying the integration process, submitting opinions, suggestions legislative proposals for consideration by the CMC and/or the national parliaments. The members of Parlasur are meant to be elected directly by the citizens of the Member States (to this date, only Paraguay, in 2008, and Argentina, in 2015, have legislated for such direct elections). Parlasur hopes to evolve into a genuine legislative body similar to the European Parliament.

22 Bellocchio, Lucía, "Resolución de Controversias en el Mercosur ¿Hacia una Corte de Justicia para el Bloque?”, Congreso de Derecho Público «Democracia y Derechos», p. 10. 
Esta revista forma parte del acervo de la Biblioteca Jurídica Virtual del Instituto de Investigaciones Jurídicas de la UNAM www.juridicas.unam.mx

ticle 40 PO further states that the national implementing measures must enter into force and be published in the official journals of the Member States 30 days following the notification by the Secretariat. As complicated as this procedure may sound, Mercosur has already enough experience with the incorporation of protocols in its legal system and nothing suggests that the incorporation of the draft protocol - once approved by the $\mathrm{CMC}$ - might encounter difficulties. ${ }^{23}$

Just as any other legislative proposal, the draft protocol contains a statement of reasons, explaining the objectives pursued. The recitals call for the establishment of a «Court of Justice of Mercosur» («CJM») as an independent judicial body, whose objective shall be the uniform interpretation and application of Mercosur law. The CJM is meant to be a contribution to the legal and institutional consolidation of the integration process. The draft protocol draws expressly from the experience gained in the application of both the protocols laying down the legal basis for Mercosur's current dispute settlement mechanism and the mechanisms in place in other integration systems characterised by a supranational format such as the EU, CAN, and SICA. The recitals confirm that the draft a protocol is essentially the product of a profound comparative study of integration law.

By using a new terminology, different from the one used at national level, the draft protocol clarifies that the CJM is supposed to become a distinct, specialised, judicial instance, anchored in the institutional framework of Mercosur. It is also evident that the drafters' intention was to depart from the arbitration model currently in place. In other words, the CJM is supposed to replace the current dispute settlement mechanism entirely. The draft protocol stresses the need to guarantee legal certainty, by pointing at the progress achieved in other integrations systems, which have developed more advanced dispute settlement mechanisms.

The recitals refer to previous resolutions of Parlasur and national supreme courts, calling for the establishment of a judicial body for Mercosur. Reference is also made to several provisions in Mercosur primary law, envisaging the establishment of a «permanent dispute settlement mechanism». All of these references indicate that the draft protocol has been ex-

23 Peña-Pinon, Mariana, "Une cour de justice pour le Mercosur? Vraies-fausses avancées vers une institutionnalisation renforcée“, Revue québécoise de droit international, 2012, 119 (147). 
pressly developed with a view to address these requests. The process of judicialisation of Mercosur is seen by the drafters as an important stage in the evolution of the integration system as a whole.

Remarkable in this context is the fact that the draft protocol refers to the CJM as a compensation for the absence of a «judicial instance of community law». Bearing in mind that it is the unanimous opinion in the TPR's case law ${ }^{24}$ and in legal theory ${ }^{25}$ that Mercosur law does not qualify as «community law» at its current stage of development, this necessarily implies that the establishment of the CJM must be understood as a step towards the transformation of Mercosur into a supranational legal system, autonomous and sui generis.

\section{B. Structure of the Draft Protocol}

\section{a. Organisational Aspects}

The draft protocol is a well-structured document, which sets out the jurisdiction, configuration and the competences of the CJM. It provides that the CJM shall be based in Asunción - the capital of Paraguay - and shall have exclusive jurisdiction for disputes concerning the legal system of Mercosur. This constitutes an important turning point in the evolution of Mercosur, in particular given the loss of confidence that some Member States had shown in the current dispute settlement mechanism in the past, demonstrated by the referral of disputes to the WTO's, rather than to the integration system's own, panel system. ${ }^{26}$ This is possible under Article 1(2) PO, which contains a choice of forum clause. According to this provision, a Member State can always choose whether to resort to the Mercosur system for the settlement of disputes or to a different mechanism to which it is a party, such as the multilateral settlement of the WTO. However, once the choice

24 TPR decision No 1/2005 of 20 December 2005, in which the TPR characterises Mercosur law as «integration law». As opposed to «community law». Which Mercosur does not yet have due to lack of «the sought-after supranational character».

25 Deluca, Santiago, "El Mercosur necesita su Maastricht”, Pensar en Derecho, 2012, p. 263.

26 Brazil had initiated a procedure against Argentina in an antidumping case by resorting first to the panel system foreseen in the PB. Dissatisfied by the panel decision, it had subsequently brought the matter before the WTO's dispute settlement system (case WT/DS 241). As a consequence, the WTO panel had been called upon to interpret Mercosur rules. 
Esta revista forma parte del acervo de la Biblioteca Jurídica Virtual del Instituto de Investigaciones Jurídicas de la UNAM

has been made and the procedures have started, the party cannot resort to a second forum.

The draft protocol reflects the principle of conferral, by providing that the CJM shall be structured and exercise its competences as stipulated therein. As regards the institutional structure, the draft protocol specifies that the CJM shall be composed of judges — whose number shall be equal to the number of Member States - and deputy judges. However, it provides for a possible increase in the number of judges and the creation of an Advocate General by the CMC upon a proposal by the CJM. By foreseeing the figure of Advocate General, the CJM clearly borrows from the European integration experience. It remains to be seen whether this provision will ever be implemented or will rather remain lettre morte, as has been the case in the CAN. While Article 6(3) of the Treaty establishing the Court of Justice of the CAN («TTJCAN») and Article 142 of its Statute provides for the creation of the figure of the Advocate General by the Andean Council of Foreign Affairs Ministers upon consultation of the TJCAN, this legal basis has not been yet invoked, allegedly due to the low number of cases. In any case, it is notable that the draft protocol refrains from defining the competences of the Advocate General, leaving the implementation to the future statute of the CJM.

Stressing the absolute independence of the members of the CJM appears to have been of paramount importance to the drafters of the protocol, which must be seen in light of the difficulties related to the current panel system. Academic lecturing is regarded as the only activity compatible with the exercise of judicial functions. The provisions on judicial independence are far-reaching and modelled after the regulation currently in place in the SICA since the establishment of its Court of Justice ( $(\mathrm{CJ}$-SICA») by the Protocol of Tegucigalpa. ${ }^{27}$

The same applies to the procedure for the selection of judges, clearly inspired by Article 10(1) of the Statute of the CJ-SICA. ${ }^{28}$ According to this

27 The Protocol of Tegucigalpa, by which the institutional framework of the SICA was modified so as to establish a judicial body, is an international treaty concluded by the Member States of the SICA on the occasion of the 11th presidential summit (held on 13 December 1991 in Managua). See, in relation to the independence of judges, the far-reaching provisions in Articles 12, 14, 15 and 29 of the Protocol.

28 The Statute of the CJ-SICA is an international treaty, which was concluded by the Member States of the SICA on the occasion of the 13th presidential summit (held on 9-11 Decem- 
procedure, the Supreme Court of each Member State shall draw up a list of candidates, following the provisions in national legislation laying down the procedure for the selection of Supreme Court judges. However, unlike the process in the SICA, where the appointment of judges is carried out by the Supreme Court of each Member State, this stage of the procedure falls within the competence of the national governments. ${ }^{29}$ The judges of CJM shall be appointed for a term of six years and are eligible for reappointment. ${ }^{30}$ In order to avoid parity in the number of judges, which might hinder majority votes, the draft protocol appears to introduce a solution foreseen in the CAN, as in those circumstances, an additional judge shall be appointed by absolute majority. With a view to ensure that the functioning of the CJM is not compromised by the absence of a judge, the draft provides for the appointment of substitute judges, who must fulfil the same professional requirements as the ordinary judges. As regards these requirements, the CJM follows the example of the EU, ${ }^{31} \mathrm{SICA},{ }^{32}$ and the $\mathrm{CAN}^{33}$, by requiring that «judges shall be chosen from persons whose independence is beyond doubt and who possess the qualifications required for appointment to the highest judicial offices in their respective countries or who are jurisconsults of recognised competence». ${ }^{34}$ Judges may only be removed by unanimous decision of CJM, upon request by all Member States, in the case of a serious violation of the fulfilment of their duties, to be specified in the CJM Statute.

Apart from judges and the possible creation of an advocate general, the draft protocol envisages that the position of the Registrar will be filled and staff will be hired by way of an international public concours.

ber 1992 in Panama) and entered into force on 2 February 1994.

29 Perotti, Alejandro, "Algunos desafíos que presenta la constitución de un Tribunal de Justicia Comunitario”, El Derecho, 2011, 8.

30 Similar to the ECJ, EFTA Court and TJCAN, whereas judges at the CJ-SICA and at the Court of Justice of the Eurasian Economic Union («CJ-EuAsEU») are appointed for a term of 10 years and 9 years respectively.

31 Article 253 TFEU.

32 Article 9 Statute of the CJ-SICA.

33 Article 6TTJCAN.

34 Other integration systems have similar criteria concerning the appointment of judges for their respective judicial bodies, for example, the EurAsEU (see Articles 9, 18-21 Statute of the CJ-EurAsEU) and EFTA (see Article 30 SCA), combining requirements of competence and independence, necessary for the fulfilment of their duties. 
The draft protocol contains detailed provisions concerning the immunities to be granted to the judges, the registrar and other staff. While judges possess the same immunity as chiefs of mission, in accordance with the Vienna Convention on Diplomatic Relations, the immunity granted to the registrar and public servants is merely functional, restrained to cover the exercise of their respective functions. The protection of the CJM's archives and official postal communication is guaranteed.

According to the draft protocol, the CJM shall adopt its statute, which shall be approved by the $\mathrm{CMC}$, following the positive vote of Parlasur. Furthermore, the CJM shall adopt its internal regulation and rules of procedure.

The draft protocol imposes certain reporting duties on CJM with regard to the Parlasur and the CMC, in order to reinforce the CJM's democratic accountability. A remarkable aspect of the draft protocol is the establishment of a system of own financial resources for the CJM. It provides that the CJM's budget shall be covered by a percentage of Mercosur's revenues derived from customs duties on imports. If this system were to be implemented, the CJM's autonomy and supranational nature would be emphasised. This would constitute a novelty in the history of South American and European integration, where integration systems rely on direct financial contributions from the Member States. ${ }^{35}$ In the EU, financial selfsufficiency is guaranteed mainly by a system composed of the traditional own resources (customs duties on imports from outside the EU and sugar levies), ${ }^{36}$ the resources based on value added tax, and a percentage of each Member State's gross national income.

\section{b. Competences and System of Procedures}

The provisions in the draft protocol setting out the competences of and the procedures before the CJM must be regarded as the most important European contribution. In the same manner as the CAN several decades ago, Mercosur transposes the European experience to the South American reality by conferring on the CJM similar competences as the ECJ.

35 Article 36 PO; Article 41 of the Statute of the CJ-SICA; Article 27TTJCAN; Article 48 SCA and Article 20 TEuAsEU.

36 See House of Lords, European Union Committee, $12^{\text {th }}$ Report of Session 2006-07, «Funding the European Union - Report with Evidence», p. 8. 
Esta revista forma parte del acervo de la Biblioteca Jurídica Virtual del Instituto de Investigaciones Jurídicas de la UNAM

\section{i. Action for Annulment}

An action for annulment can be brought against any act of secondary law adopted by the CMC, the GMC, the CCM, and other bodies of Mercosur which is in violation of the integration system's legal system, in particular against ultra vires legal acts. Plaintiffs can be any Member State, Parlasur, the $\mathrm{CMC}$, the GMC, the CCM, the Secretariat or - provided that their rights and legitimate interests are affected — individuals. The CJM thus adopts the distinction between so-called preferential and non-preferential plaintiffs known in EU law. One interesting difference lies, however, in the fact that active legitimacy can be extended to other Mercosur bodies by decision of the CMC, upon proposal from the CJM and approval of the Parlasur.

Another important characteristic of the rules introduced by the draft protocol is the more generous access to justice granted to individuals, made possible by an active legitimacy defined in broader terms. As already mentioned, individuals may challenge legal acts also when their «legitimate interests» are affected, as is nowadays also the case under CAN law. ${ }^{37}$ This clearly distinguishes South American procedural law from European procedural law with its two main representatives _ EU law ${ }^{38}$ and EEA law_— ${ }^{39}$ under which active legitimacy is granted to the addressee of the legal act in question and to anyone else provided that this legal act be of his «direct and individual concern». This difference becomes more evident in view of the strict interpretation given to this legal requirement by the European Courts i.e. the ECJ and EFTA Court. ${ }^{40}$

The application of the action for annulment does not suspend or affect the validity of the legal act challenged. However, the CJM may, upon request by any of the parties to the procedure, order the provisional suspension of the legal act challenged or adopt other interim measures, if the application of the act or the absence of the interim measures cause irreparable damages to any of the parties.

37 Article 19TTJCAN.

38 Article 263(4) TFEU.

39 Article 36(2) SCA.

40 Judgment in Deutsche Post AG and Germany. / Commission, Joined Cases C-463/10 P and C-475/10 P, EU:C:2011:656, paras. 37-38; E-2/02 Technologien Bau- und Wirtschaftsberatung GmbH and Bellona Foundation [2003] EFTA Ct. Rep. 52, paras. 41-79. 
The draft protocol enables the CJM to specify the temporal effects of its judgment in case that it should declare the total or partial annulment of the legal act challenged. It imposes on the Mercosur body whose act has been annulled the obligation to adopt the necessary measures to guarantee compliance with the judgment within the time limit specified by the CJM.

The time limit for an action for annulment is six months after the entry into force of the legal act challenged. However, in a legal dispute concerning the validity of a legal act, any of the parties of the procedure may raise the question of its applicability before the CJM for the same reasons as in an action for annulment. This incidental plea in law is modelled after the objection of illegality enshrined in Article 277 TFEU and serves the same purpose, namely to allow parties to challenge the legality legal acts despite the fact that the time limit for an action for annulment may have expired or that the parties may have no legal standing to challenge these acts. ${ }^{41}$

\section{ii. Action for Failure to Act}

An action for failure to act can be filed whenever the Parlasur, CMC, GMC, $\mathrm{CCM}$ or the Secretariat should fail to adopt a measure, in violation of an obligation derived from Mercosur law. As is the case in EU law, the draft protocol uses a broad terminology to define the requested measure («medida»; «actividad»), which also encompasses non-legally binding acts. ${ }^{42}$ Active legitimacy is given to the Member States, Parlasur, the Secretariat and individuals, in so far as their rights or legitimate interests are affected. The action is admissible if the respective Mercosur body has failed to adopt a

41 Lenaerts, Koen et al., EU Procedural Law, Oxford 2014, p. 442.

42 In the EU, the duty to take a decision or other sort of action requested must give rise to an act that is capable of having legal effects. The nature of the legal effects required, however, is not always the same. In depends on the status of the party bringing the action. EU law distinguishes, in Articles 265(1) and (3) TFEU, between, on the one hand, actions filed by EU institutions as a result of a general failure by another institution to act according to obligations derived from the EU Treaties and, on the other hand, actions aimed at the adoption of a legal act («other than a recommendation or an opinion») addressed to an individual. A similar concept can be found in Article 37(1) and (3) SCA for the EFTA pillar of the EEA («any decision»), whereas the draft protocol on the CJM and CAN law do not appear to make such a distinction. Instead the respective provisions are framed in general terms, so as to encompass different types of measures or activities foreseen in integration law. This is similar in Eurasian law, as Article 39 of the Statute of the CJ-EurAsEU merely refers to «omissions». 
Esta revista forma parte del acervo de la Biblioteca Jurídica Virtual del Instituto de Investigaciones Jurídicas de la UNAM

favourable decision within 30 days after the request to act has been submitted. ${ }^{43}$ Should the CJM consider the action founded, then it shall adopt a judgment based on the technical information available, containing the antecedents of the case, the explanations of the respondent body, as well as the form, modality and time-limit for the fulfilment of its obligation.

\section{iii. Action for Infringement}

An important novelty in the procedural law of Mercosur, crucial to survey compliance by the Member States with their obligations derived from this integration system's legal order, is the introduction of the action for infringement, designed after the model in place in the EEA and the CAN. ${ }^{44}$ However, contrary to the original model, the draft protocol foresees a number of remarkable differences. For instance, it envisages that the action for infringement may not be only filed by, alternatively, a surveillance body (EU: European Commission; EEA/EFTA: EFTA Surveillance Authority; CAN: Secretaría General) or another Member State. In this respect, the draft protocol goes beyond what is known in the other integration systems by extending this competence to additional actors such as Parlasur, the Secretariat and - subject to certain conditions, which shall be explained in detail - even to individuals. All of these actors are presumed to act in the general interest of safeguarding the legality of State action.

The draft protocol follows the original European ${ }^{45}$ and Andean ${ }^{46}$ model by distinguishing between a pre-litigation and litigation stage. In the pre-

43 The deadline is of 2 months in the EU (Article 265(2) TFEU) as well as in the EFTA pillar of the EEA (Article 37(2) SCA), and 30 days in the CAN (Article 37(2) TTJCAN).

44 Unlike the Eurasian system, which no longer has any similar procedure to pursue infringements under the Treaty of the EurAsEU, in force since 1 January 2015. The dispute settlement mechanism of the former EurAsEC used still to foresee that the Eurasian Economic Commission could «notify» the Member State in question of the need to eliminate the violation of integration law within a «reasonable» period of time; if the latter failed to do so, the Board of the Eurasian Economic Commission would then refer the issue to the Commission's Council. Only if the Member State ignored the Council's decision, the Board would refer the case to the Court of Justice of the EurAsEC (see further Blockmans, Steven/ Kostanyan, Hrant/Vorobiov, Ievgen, "Towards a Eurasian Economic Union: The challenge of integration and unity", CEPS Special Report, No 75, 2012, p. 16.

45 Article 258(1) and (2) TFEU; Article 31(1) and (2) SCA.

46 Article 23(1) and (2) TTJCAN. 
Esta revista forma parte del acervo de la Biblioteca Jurídica Virtual del Instituto de Investigaciones Jurídicas de la UNAM

litigation stage, the Secretariat shall confront the Member State with the alleged breach of Mercosur law in writing, to which the latter shall reply within a deadline of 30 days. After the receipt of the reply, the Secretariat shall submit a reasoned opinion containing an assessment of the alleged breach, with a deadline for reply of 15 days. If the opinion finds a breach and the Member State were to persist in its behaviour, the Secretariat shall refer the matter to the CJM. Any other Member State affected is allowed to join the action in support of the Secretariat. While the original European ${ }^{47}$ and Andean model provides that the executive body in charge of pursuing breaches of the integration system's law shall have discretion as to whether to take action against a Member State (a fact reflected by the wording of the respective provisions), the draft protocol appears to use a stricter wording («deberá iniciar, de forma inmediata, la acción de cumplimiento»), suggesting that the Secretariat might be obliged to bring an action before the CJM in all circumstances.

As is the case in the EEA and in the CAN, the action for infringement can be initiated by another Member State, provided that it first lodges a complaint before the respective executive body in charge of pursuing breaches. Under this procedure, the same deadlines for the pre-litigation stage referred to above apply. Should the Secretariat not refer the matter to the CJM within 60 days after having presented its reasoned opinion, the Member State may then bring the action by itself. It has this right as well in a situation, in which the Secretariat might not have submitted a reasoned opinion at all, for which a waiting period of 65 days after the filing of the complaint applies. Contrary to the provisions regulating the infringement procedure carried out by the Secretariat on its own motion, the Member State is awarded discretion («el Estado Parte reclamante podrá iniciar la acción de incumplimiento»). The procedure described in this paragraph applies for any action for infringement initiated by Parlasur.

Another difference from the European and Andean model is that the draft protocol grants individuals active legal capacity to pursue infringements of Mercosur law in the event that their rights might have been violated. However, this remedy requires that individuals first undergo the procedure described above, which implies lodging a complaint before the Secretari-

47 Judgment in Commission ./. Germany, C-383/00, EU:C:2002:289, para. 19; E-2/13 Bentzen Transport ./. EFTA Surveillance Authority [2013] EFTA Ct. Rep. 803, para 40. 
at before being able to file an action. Remarkably, the use of this remedy expressly precludes the individual's right to call the competent national courts on grounds of a breach of Mercosur law by a Member State. While this provision, which is clearly inspired by $\mathrm{CAN}$ law, ${ }^{48}$ appears to prevent contradictory judicial decisions at supranational and national level, it is worth noting in this context that such a risk is rather unlikely. As practical experience shows, the risk that a national court might come to a contradictory interpretation and/or application of integration law is averted by the fact that national courts are usually entitled to submit a request for a preliminary ruling aimed at clarifying controversial questions of interpretation. Any judgment delivered by the CJM constitutes a suitable legal basis for individuals seeking reparation for damages before national courts on the basis of State liability for breach of Mercosur law. Here, Mercosur law leans more towards CAN law, which contains essentially the same provision, ${ }^{49}$ whereas in EU law, an ECJ judgment alone cannot be used as a legal basis for a claim based on State liability. It would rather require a judgment, either of the ECJ or a national court, concluding that the legal requirements for State liability established in the case law of the ECJ - in particular, the existence of a «sufficiently serious breach» of a provision of EU law «conferring a right» on individuals - are met in the case in issue. ${ }^{50}$

After a breach of Mercosur law has been established, the respective Member State has a deadline of 90 days to take the necessary measures to comply with the CJM judgment, unless a different deadline has been set. The draft protocol provides that the CJM judgment shall be binding upon

48 Article 31 in conjunction with Article 4 TTJCAN provides that individuals may call upon national courts in accordance with national rules in cases where Member States fail to adopt the necessary measures to ensure compliance with CAN law, resulting in a breach of their individual rights.

49 Article 30TTJCAN.

50 The finding of a failure to fulfil obligations may potentially form the basis for liability on the part of the Member State concerned (Transportes Urbanos y Servicios Generales, C-118/08, EU:C:2010:39). However, in accordance with the case law, a Member State may incur liability only in the case of a «sufficiently serious breach» of EU law. A judgment finding a failure to fulfil obligations is in itself not enough (Danske Slagterier, C-445/06, EU:C:2009:178). The requirement for a «sufficiently serious breach» does not square completely with the strict or objective nature of an action for failure to fulfil obligations, since the ECJ also takes other factors into account, such as whether or not the breach was intentional and whether any mistake of law was excusable. 
all Member States and Mercosur bodies. As regards the measures available to the CJM in the case that the Member State should not have fulfilled this obligation, the draft protocol borrows from EU law ${ }^{51}$ the faculty to impose a lump sum or a penalty payment. ${ }^{52}$ By doing this, the draft protocol clearly rejects the models currently in place in Mercosur itself, ${ }^{53} \mathrm{CAN},{ }^{54}$ and SICA, ${ }^{55}$ which allow Member States to resort to either compensatory measures (in the case of Mercosur) or countermeasures (in the case of CAN and SICA) against other Member States. While the first model is inspired by WTO law, the second one bears some similarity with the instrument of «lawful reprisal» known in public international law. ${ }^{56}$ It must be assumed that the drafters were aware of the risks that such a system has for the stability of an integration system. In fact, an integration system, which allows its Member States to resort to reprisal without addressing the precise origin of the dispute, will be undermined in the long term if the conflict escalates. A series of reprisal measures is unlikely to allow the integration system to re-establish the mutual trust shattered by the dispute. On the other hand, it cannot be ruled out that certain Member States might refrain entirely from

51 Article 260(2) TFEU.

52 An option not available in the dispute settlement mechanism foreseen in the EFTA pillar of the EEA, which must rather rely on ESA's readiness to launch subsequent infringement proceedings pursuant to Article $33 \mathrm{SCA}$, aimed at establishing that the respective EFTA State has failed to comply with the EFTA Court judgment (see further Sletnes, The EFTA Surveillance Authority and the Surveillance of the EEA Agreement, in: EFTA Court, The EEA and the EFTA Court, Decentred Integration, 2014, p. 501-506, p. 504; Case E-19/14 EFTA Surveillance Authority . / . Norway, para. 41). Article 114 of the Statute of the CJ-EurAsEU provides that if there is no implementation within a given period of time, the aggrieved party can turn to the Supreme Council, or in other words, seek a high-level, political remedy (see Dragneva/ Wolczuk, Eurasian Economic Integration: Institutions, Promises and Faultlines, The Geopolitics of Eurasian Economic Integration: Special Report 19, p. 12).

53 Chapter IX of the PO.

54 Article 27TTJCAN.

55 Article 39(2) of the Statute of the CJ-SICA.

56 Reprisals in international law contexts were defined in the Naulilaa Case (Portugal ./. Germany), 2 UN Reports Of International Arbitral Awards 1012 (Portuguese-German Mixed Arbitral Tribunal, 1928): «A reprisal is an act of self-help... by the injured state, responding - after an unsatisfied demand - to an act contrary to international law committed by the offending state... Its object is to effect Reparation from the offending state for the offense or a return to legality by the avoidance of further offenses». 
adopting authorised countermeasures out of fear of reprisals, ${ }^{57}$ ultimately putting into question the system of law enforcement. It is exceptionally, and only on the basis of good reason, that the CJM may impose sanctions in addition to a lump sum or a penalty payment, such as the restriction or the suspension of advantages granted to the Member State in breach of Mercosur law, including voting rights in Mercosur bodies. However, the draft protocol seems to take the concerns voiced above into account, as the CJM may refrain from imposing restrictions and rather opt for alternative - unspecified - sanctions if the restrictions were to exacerbate the situation or to be inefficient.

The judgment delivered by the CJM shall be final and have effect of res iudicata. However, in order to prevent irreparable damages, any of the intervening parties may request the adoption of interim measures, such as the provisional suspension of the act allegedly in breach of Mercosur law. Furthermore, the CJM is entitled to review its own decision, upon request by any of the parties, on the basis of a decisive fact unknown at the time of the delivery of the judgment. The time limit for the submission of this request is of 90 days. This legal remedy is aimed at striking a balance between legal certainty on the one hand and material justice on the other hand, and is clearly modelled after the provision laid down in Article 29TTJCAN.

\section{iv. Preliminary Ruling Procedure}

An important novelty of the draft protocol is the introduction of the preliminary ruling procedure, designed after the model in place in the EU and the CAN. The CJM shall have jurisdiction to give preliminary rulings concerning the interpretation or validity of Mercosur law upon request by the national courts. The draft protocol specifies that a national court may bring the matter before the CJM on its own motion or upon request by any of the parties of the procedure. ${ }^{58}$ In the same way as in the EU and the CAN,

57 Sasaki Otani, María Angela, "El sistema de sanciones por incumplimiento en el ámbito de la Comunidad Andina”, Anuario Mexicano de Derecho Internacional, 2012, 301 (318).

58 The draft protocol is therefore more precise than European and Andean law as regards a possible «right» of the parties of the main proceedings to request a referral to the supranational court. The wording of Article 267(2) TFEU, Article 34(2) SCA and Article 33(1) TTJCAN is, on the contrary, rather neutral, suggesting that a referral constitutes the sole prerogative of the national judge, who shall determine its necessity for the resolution of the legal 
the draft protocol distinguishes between the facultative and the obligatory referral, depending on whether there is a judicial remedy under national law against the national court's decision or not. Contrary to the European and the Andean model, the draft protocol extends the right to refer questions of interpretation or validity to other Mercosur bodies, namely Parlasur, CMC, GMC, CCM and the Secretariat. From that perspective, the system envisaged appears to have borrowed aspects from SICA, which provides for an «advisory opinion procedure» reserved to national $\operatorname{courts}^{59}$ as well as for a «consultation procedure» available to other bodies, ${ }^{60}$ aimed both at obtaining an interpretation of the rules of the integration system. ${ }^{61}$

Interestingly, even though the draft protocol states that a national court envisaging a referral to the CJM must suspend the national procedure, it explicitly acknowledges the national court's right to rule on the case even without having to wait for the CJM's preliminary ruling. This provision is derived from Andean law, which prescribes in Article 33 TTJCAN that the suspension of the national procedure by the iudex a quo only in the case of an obligatory referral, whereas a referral does not have the effect of suspending the national procedure if it is merely facultative. Consequently, in the latter case, the national judge may adopt a decision resolving the dispute even before the supranational court has had the opportunity to rule on the questions submitted for interpretation. ${ }^{62}$ It is questionable whether this provision contributes to the efficiency of the system, given the considerable amount of resources often used in the framework of a single referral procedure.

dispute. This interpretation has been confirmed in case law (Judgment in Kelly . / National University of Ireland, C-104/10, EU:C:2011:506, paras. 61, 64; E-18/11 Irish Bank Resolution Corporation Ltd . /. Kaupping hf [2012] EFTA Ct. Rep. 592, para. 55; Case 149-IP-2011, p. 8).

59 Article 22 lit. $k$ of the Statute of the CJ-SICA.

60 Article 22 lit. e of the Statute of the CJ-SICA.

61 As mentioned above, the Eurasian integration system has been deprived of its mechanism of preliminary ruling with the entry into force of Treaty on the EurAsEU. Instead, the Statute of the CJ-EurAsEU, contained in Annex II to that treaty, provides in Article 46 for the competence to provide clarifications by means of advisory opinions to provisions of the treaty upon request of a Member State or an EurAsEU body.

62 This is not the case in the SICA, where a suspension of the national procedure is considered to be a necessary step before any referral to the CJ-SICA (see further Salazar Grande, César Ernesto and Ulate Chacón, Enrique Napoleón, Manual de Derecho Comunitario Centroamericano, 2nd edition 2013, p. 301). 
Esta revista forma parte del acervo de la Biblioteca Jurídica Virtual del Instituto de Investigaciones Jurídicas de la UNAM

It is worth noting in this context that the above mentioned provision of the draft protocol allowing the national court to rule on the case without having to wait for the CJM's preliminary ruling is likely to pose similar problems as in the legal situation, which existed in the EU before the latest reform of the ECJ's Rules of Procedure. Article 100 of the ECJ's new Rules of Procedure recognises the national court's right to withdraw its request for a preliminary ruling, with certain restrictions. According to this provision, the withdrawal of a request may be taken into account until notice of the date of delivery of the judgment has been served on the interested persons referred to in Article 23 of the ECJ's Statute. This provision must be interpreted as an attempt to strike a balance between the procedural autonomy, which every national court possesses, on the one hand and the interest in developing the case law of the ECJ on the other hand, let alone in not wasting the precious personal and material resources invested in the procedure before the ECJ. In order to avoid any doubts regarding the binding nature of the judgment delivered by the CJM, which constitutes a turning point in the history of Mercosur procedural law, the draft protocol states that the national court must apply the answer provided to the case brought before it. ${ }^{63}$ It further states that the Member States and the Mercosur bodies shall ensure that national courts strictly comply with the rules regulating the preliminary ruling procedure. The reference to Mercosur bodies in this context might be understood as an implicit statement that Member States are - despite the judicial independence awarded to judicial bodies under national constitutional law - not exempt from facing infringement proceedings for their courts' failure to comply with CJM case law or with the duty to request preliminary rulings. ${ }^{64}$

63 Decisions adopted by the judicial bodies of integration systems upon referrals by national courts are binding with effect inter partes — despite the fact that they may have certain authority for the resolution of similar disputes - in the EU (Judgment in Elchinov . / Natsionalna zdravnoosiguritelna kasa C-173/09, EU:C:2010:581, para. 29), CAN (Case 156-IP-2011) and SICA (Articles 3 and 39 Statute of the CJ-SICA; Case No. 1-27-05-2011, p. 5). Although advisory opinions of the EFTA Court do not have binding effect, they provide an authoritative interpretation of EEA law. Consequently, ESA may launch infringement proceedings pursuant to Article 31 SCA should an EFTA State disregard this interpretation.

${ }^{64}$ The possibility for the surveillance body (European Commission/Secretaría General) to launch infringement proceedings in the event of a violation of the duty to refer questions concerning the interpretation of integration law is recognized in the case law of the ECJ (Judgment in Commission . /. Italy, C-129/00, EU:C:2003:656) and the TJCAN (Case 180-IP- 
Esta revista forma parte del acervo de la Biblioteca Jurídica Virtual del Instituto de Investigaciones Jurídicas de la UNAM

\section{v. Arbitration}

The draft protocol borrows from the TTJCAN legal provisions conferring on the CJM jurisdiction to give judgment on the basis of an arbitration clause. ${ }^{65}$ They do not entirely correspond to those laid down in the EUTreaties $^{66}$ and are also considerably more detailed than the provisions regulating the competence of the CJ-SICA in arbitration matters ${ }^{67}$ According to these provisions, the CJM shall have jurisdiction in disputes concerning the application or interpretation of contracts or agreements concluded between Mercosur bodies and third parties if they agree. Furthermore, natural and legal persons may submit disputes to arbitration concerning the application or interpretation of private law contracts governed by Mercosur law. The CJM is entitled to rule on the basis of law or equity, depending on the choice of the parties.

\section{vi. Staff Matters}

Last but not least, the CJM shall have jurisdiction in staff matters. By so doing, Mercosur follows the model established in the $\mathrm{EU}^{68}$ and the $\mathrm{CAN},{ }^{69}$ which envisages the creation of a special jurisdiction, detached from the national court systems. The draft protocol distinguishes between officials and contract agents, who shall nonetheless be equally subject to the CJM's jurisdiction. The provisions specify that staff member shall have access to

2011, p.10). In the EFTA pillar of the EEA, Article 34 SCA imposes no corresponding duty. However, the EFTA Court held that «courts against whose decisions there is no judicial remedy under national law will take due account of the fact that they are bound to fulfil their duty of loyalty under Article 3 EEA». (E-18/11 Irish Bank Resolution Corporation Ltd . / . Kaupping hf [2012] EFTA Ct. Rep. 592, para. 58) Moreover, it was found in Case E-3/12 that «it is equally important that such questions are referred to the Court under the procedure provided for in Article 34 of the Agreement between the EFTA States on the Establishment of a Surveillance Authority if the legal situation lacks clarity (E-3/12 Staten v Arbeidsdepartementet ./. Stig Arne Jonsson [2013] EFTA Ct. Rep. 136)».

65 Article 38 TTJCAN.

66 Articles 272-273 TFEU.

67 Article 22 lit. ch Statute of the CJ-SICA.

68 Articles 257 and 270 TFEU; Annex I to the Statute of the ECJ; Council Decision of 2 November 2004 establishing the European Union Civil Service Tribunal.

69 Article 40 TTJCAN; Articles 135-139 Statute of the TJCAN. 
the CJM provided that the administrative legal remedies be exhausted. This implies inter alia lodging a complaint before the highest instance of the Mercosur body concerned. The principle of exhaustion of administrative legal remedies before the matter can be referred to the judicial body of the integration system is also reflected in the EU. ${ }^{70}$

\section{c. Types and Legal Effects of Judicial Decisions}

Chapter II of the draft protocol deals with the legal effects of judicial decisions. This concerns first of all the interim measures, which the CJM may order in specific circumstances, as has been already explained. Furthermore, the draft protocol refers to the binding and direct effect of judicial decisions, which shall be enforceable in the same way as any of a national court without other formality than verification of the authenticity of the decision by the CJM. From that viewpoint, this regulation is similar to Article 280 TFEU in conjunction with Article 299 TFEU, even though it rather appears to be modelled after Article 41 TTJCAN and Article 39 CJ-SICA.

The draft protocol creates with the CJM a single jurisdiction - as is nowadays the case for the TJCAN, the CJ-SICA, the CJ-EurAsEU, as well as for the EFTA Court, or the ECJ (prior to the creation of the Court of First Instance) - with the consequence that its judgments are final and appeals are not admissible. However, for the sake of legal certainty, the draft protocol stipulates that the CJM shall be entitled to clarify or extend the scope of its judgments either on its own motion or upon request by any of the parties to the main proceedings within 30 days after its notification. This procedure appears to have as its model the procedure laid down in Article 38 of the Statute of the CJ-SICA, as the provisions have the exact same wording. A similar procedure is foreseen in Article 92(1) TTJCAN, except that the latter provides for a time limit of 15 days. The true origin of all these procedures seems, however, to be in Article 43 of the ECJ's Statute, which allows the parties of a procedure and/or an EU institution to request the interpretation of judgments or orders of the ECJ and the General Court if the meaning of the judicial decision in question is in doubt. The resort to this procedure under EU law is however more generous than under the draft protocol and CAN law, as the ECJ's Rules of Procedure require that

70 Judgment in Coedo Suárez ./. Council, Case F-73/10, EU:F:2011:102. 
an application for interpretation should be made within two years after the date of delivery of the judgment or the service of the order. ${ }^{71}$ By contrast, no time limit is prescribed in the General Court's Rules of Procedure. ${ }^{72}$

The change from the current legal regime of panel decisions clearly has been of major concern to the drafters, as the protocol reiterates the binding effect of all decisions adopted by the CJM upon the Member States, Mercosur bodies as well as natural and legal persons. It further states that these decisions shall be published in the Official Journal of Mercosur, unless decided otherwise.

\section{d. Jurisdictional Matters}

As already mentioned, the draft protocol provides that the CJM shall have exclusive jurisdiction for disputes arising in connection with the legal system of Mercosur. This provision is the consequence of the negative experience made by Mercosur in the past and accordingly follows the European, ${ }^{73}$ Andean, and Central American model, which foresee the exclusive jurisdiction of their dispute settlement mechanisms in Article 344 TFEU, Article 108(2) EEA, Article 42(1) TTJCAN, ${ }^{74}$ and Article 3 of the Statute of the CJ-SICA respectively. ${ }^{75}$

71 Article 158(2) of the Rules of Procedure.

72 Lenaerts, Koen/Maselis, Ignace/Gutman, Kathleen, EU Procedural Law, Oxford 2014, p. 859 .

73 It is worth mentioning in this context that there is no similar provision in the Statute of the CJ-EurAsEU (Karliuk, Maksim, WP BRP 53/LAW/2015 of National Research University Higher School of Economics, 2016, p. 18). It seems that the judicial body of the Eurasian integration process has lost its exclusive competence and that national jurisdictions will be allowed to interpret Eurasian law on their own right. This understanding appears to be in line with Article 47 of the Statute, which provides that «providing clarifications by the Court shall mean providing an advisory opinion and shall not deprive the Member States of the right for joint interpretation of international treaties» (see further Borovikov, Edward/Danilow, Igor, "B2B: Balancing the Court of the Eurasian Economic Union", in: The Moscow Times of 17 March 2015, in: http://www.themoscowtimes.com/article/b2b-balancing-the-court-of-the-eurasian-economic-union/517551.html (last visited on 2 June 2016).

74 Secretaría General ./. Ecuador, Case 2-AI-97.

75 Whilst Article 3 of the Statute of the CJ-SICA merely states that the court shall have jurisdiction to settle disputes and that its decisions shall have binding effect on all States and bodies being part of the integration system as well as on individuals, this provision is com- 
In addition, the draft protocol provides that Member States and Mercosur bodies may decide to accept the CJM's jurisdiction in their relations with third party States or groups of states. While this provision is clearly modelled after Article 42(2) TTJCAN, it is in line with EU law as well. It is worth recalling in this context that, as the ECJ has stated in its case law concerning jurisdictional matters, an international agreement concluded with third party States may confer new judicial powers on the ECJ provided that in so doing it does not change the essential character of the function of the ECJ as conceived in the EU Treaties. ${ }^{76}$ Similar competences have been conferred upon both the CJ-SICA ${ }^{77}$ and the CJ-EurAsEU. ${ }^{78}$

The draft protocol borrows elements found in CAN law as regards the conferral of the necessary powers to fulfil its functions in practice. The legal provisions in question essentially replicate the competences foreseen in Articles 44 and 45 TTJCAN. These powers imply maintaining relations with inter alia the Member States and Mercosur bodies. Moreover, the draft protocol states that the CJM shall coordinate meetings and actions with the highest judicial authorities of the Member States with a view to promote the knowledge and the development of Mercosur law as well as its uniform application.

\section{e. General Provisions}

As in any other international legal system, the draft protocol is expected to provide for a regulation concerning the linguistic regime. By declaring Spanish and Portuguese as the official languages in all legal proceedings, the draft protocol retains the linguistic regime of the dispute settlement mechanism currently in place in Mercosur.

While the CJM is supposed to replace the current dispute settlement mechanism, the draft protocol clarifies that the provisions of the PO shall remain applicable to pending legal proceedings. This regulation confirms the view that the draft protocol's objective is by no means to set up an entirely new integration system with a distinct legal personality. The legisla-

monly understood as referring to the court's exclusive jurisdiction. This is also unambiguously stated in the recitals.

76 Opinion 1/92, EEA II, ECLI:EU:C:1992:189, point 32; Opinion 1/09, European Patent Tribunal, ECLI:EU:C:2011:123, point 75 .

77 Article 22 lit. $h$ of the Statute of the CJ-SICA.

78 Article 48 of the Statute of the CJ-EurAsEU. 
tive amendments must rather be construed as meaning that they only concern Mercosur's dispute settlement mechanism. The situation in Mercosur can therefore not be compared to the evolution experienced in the Eurasian area, in which a distinct Court of Justice has been created with the establishment of the Eurasian Economic Union («EurAsEU») on 1 January 2015. Even though the Eurasian Economic Community («EurAsEC») preceded this integration system until its dissolution on 1 January 2015 and had a court of justice of its own, it is not possible to speak of legal succession between these two international organisations. Accordingly, the CJ-EurAsEU as such does not have jurisdiction for disputes concerning the legal system of the EurAsEC. Consequently, despite the expected considerable effects of the reform of Mercosur's dispute settlement mechanism, which might entail its transformation into a supranational legal system, the amendments remain confined within the same integration system.

The draft protocol, once approved, will be a separate legal instrument of public international law, which will nonetheless constitute part of the Mercosur acquis. In line with the CJM's exclusive jurisdiction in Mercosur law matters, the draft protocol provides that any State acceding to the TA shall accede ipso iure to the protocol. Conversely, any withdrawal from the protocol implies the withdrawal from the TA. A similar provision can be found in Article 51 of the Agreement between the EFTA States on the establishment of a Surveillance Authority and a Court of Justice («SCA») for the EEA.

\section{f. Transitional Provisions}

The draft protocol contains provisions, which regulate the transition from the current dispute settlement regime to the new one. They state time limits for the first appointment of judges, the completion of the establishment of the CJM, the adoption of its Statute and Rules of Procedure, as well as the adoption of the regulation establishing a system of own financial resources.

\section{g. Sources of Integration Law}

It is worth noting that the draft protocol provides in its preamble that the CJM shall «interpret» and «state» integration law, however without referring to the sources of Mercosur law, contrary to what had been the approach to date under Article $1 \mathrm{PO}$. As the PO —regulating the arbitration 
system currently in place - is most likely to be repealed after the draft protocol has entered into force, it will be necessary to rely on Article 41 of the Protocol of Ouro Preto («POP»), with lists up these sources. Mercosur would therefore take a different approach from CAN, EFTA, and EuAsEU, which indicate in the founding legal instruments of their respective judicial bodies the law to be applied for the resolution of disputes. ${ }^{79}$ As a matter of comparison, it should be mentioned that the founding legal instruments of the respective judicial bodies of SICA and the EU merely refer to their respective forms of integration law in general, with a catalogue of legal act types contained in respectively Article 9 of the Reglamento de los Actos Normativos del SICA and Article 288 TFEU.

Common to almost all legal orders, in which the aforementioned judicial bodies operate, is that they view themselves as sui generis and autonomous, distinct from national and public international law, either if they are to be classified as «Community law» ${ }^{80}$ or as being at an «intermediate stage». ${ }^{81}$ Only the Statute of the CJ-EuAsEU raises questions as regards the precise nature of Eurasian law, ${ }^{82}$ as it explicitly refers to public international law as one of its sources. ${ }^{83}$

\section{Conclusions}

The draft protocol on the creation of CJM constitutes a compilation of legal provisions inspired by the legal orders of other integration systems in both

79 Article 1 TTJCA; Article 1 lit. a SCA; Article 50 of the Statute of the CJ-EurAsEU.

80 This is the case of the EU (Judgment in NV Algemene Transport-en Expeditie Onderneming van Gend \& Loos ./. Netherlands Inland Revenue Administration, C-26/62, EU:C:1963:1; Judgment in Costa ./.E.N.E.L., C-6/64, EU:C:1964:66), of the CAN (Cases 2-AI-97; Case 3-AI96; 2-IP-90), and of the SICA (CCJ, Decisions 4-1-12-96; N 05-08-97).

81 This is the case of the EEA (E-7/97 Sveinbjörnsdóttir [1998] EFTA Ct. Rep. 127, para. 59; E-4/01 Karlsson [2002] EFTA Ct. Rep. 240, para. 25) and of Mercosur (TPR, Decisions No 1/2005; No 1/2007; No 1/2009).

82 Certain aspects, such as the regulatory competence of the EurAsEU Commission-its executive body-and the supremacy of its Customs Code over national law, suggest that it combines supranational and intergovernmental elements.

83 Article 50 of the Statute of the CJ-EurAsEU reads: «In the exercise of justice, the Court shall apply: 1) the generally recognised principles and regulations of international law (paragraph 1); 4) the international custom as evidence of the general practice accepted as a rule of law». 
Esta revista forma parte del acervo de la Biblioteca Jurídica Virtual del Instituto de Investigaciones Jurídicas de la UNAM www.juridicas.unam.mx

the Americas and Europe. While the influence of CAN and, to a lesser extent, SICA is palpable, it is worth noting that most provisions ultimately relate to the legal order created by the EU. This concerns, for the most part, the system of procedures and remedies, which has been adopted with only few modifications. The same applies to the system of financial penalties for breach of integration law, what might ultimately make of Mercosur the only integration system in America to put in place such a mechanism of legal enforcement. However, the fact that the draft protocol partially adheres to a system of countermeasures in order to ensure enforcement, as is the case in CAN and SICA, indicates that the drafters were still cautious as regards the possible acceptance of a system of financial penalties by the Member States.

The dispute settlement mechanism envisaged is meant to replace a system of arbitration which has become obsolete for an integration system such as Mercosur, whose ambitious objective is to create a common market comprising the largest economies in South America. The tendency goes clearly towards the adoption of supranational features, leaving behind the intergovernmentalism of the past. Safeguards such as independence in financial matters as well as regards the appointment of judges shall ensure that the future CJM will operate efficiently, shielded from any possible intervention by national governments. The ultimate purpose is the consolidation of the Mercosur legal order as one distinct from national and international law, which shall evolve into community law. This aspiration can be deduced from the draft protocol and from the diverse decisions adopted by the TPR, which essentially acknowledge that Mercosur law is still at an early stage of development. It further follows from the recitals to the preamble and the explanations attached to the draft protocol that the drafters hoped for more professionalism in the exercise of judicial functions, liable to contribute to an improvement of the quality of Mercosur jurisprudence. Unfortunately, at this stage, certain panel and TPR decisions reveal a lack of legal creativity, with solutions often «imported» from the findings of other supranational courts. The involvement of permanent judges shall hopefully help the CJM to develop its own case law, derived from an inward and rigorous analysis of Mercosur law. Ultimately, depending on the success of the CJM, Mercosur law might advance to becoming an additional source of supranational integration law worldwide, contributing to a more authentic «judicial dialogue» withTJCAN ${ }^{84}$ and other supranational courts, instead of remaining confined

84 Kühn, Werner Miguel, "Reflexiones sobre una possible convergencia regional con la 
Esta revista forma parte del acervo de la Biblioteca Jurídica Virtual del Instituto de Investigaciones Jurídicas de la UNAM

to the role of the receiver, which processes and transposes foreign case law (mainly from CAN and EU).

The draft protocol can be seen as an answer to the long debated question as to whether Mercosur could evolve into a supranational legal order by itself, relying exclusively on the efforts undertaken by its dispute settlement bodies and the case law produced, or rather by the creation of a judicial body with far-reaching competences, such as ECJ, EFTA Court, and TJCAN. Experience has shown that an arbitration system cannot deliver the expected results, due to its lack of continuity, professionalism and long-term perspective. Neither could it be expected that powerful Member States would relinquish their bargaining power in negotiations in favour of a more balanced system, which promotes the formal equality between Member States for the sake of the stability of integration process. Against this backdrop, the creation of a supranational court would constitute a radical turning point in Mercosur's history. Eventually, such a step might provide stimuli for other integration systems around the world to follow the example. As can be seen in the case of the CJ-EuAsEU, integration does not necessarily entail a continuous increase in the competence of judicial bodies but sometimes even the loss thereof. ${ }^{85}$

\section{THE WAY AHEAD}

Although five years have passed since Parlasur submitted the draft protocol for approval, the idea of establishing the CJM has not been abandoned. On

participación de la Comunidad Andina y el Mercosur. Lecciones de la experience integracionista europea”, Politica Internacional, 2013, p. 192, concerning the proposal concerning the creation of a legal mechanism aimed at establishing a link between CAN and Mercosur, which would make their legal orders compatible with each other. The ultimate objective would be to create an integrated «South American Economic Area», in which both, TJCAN and a future CJM would play a crucial role in the interpretation of the common integration law.

85 The Statute of the CJ-EurAsEU shows a clear intention to limit its competences and authority. A few examples are the already mentioned abolishment of the mechanism or preliminary ruling, the authorisation of joint interpretations by the Member States themselves (article 47), the prohibition on the CJ-EurAsEU to vest additional competences to the bodies of the integration system (article 42) or to create new legal provisions, including in national legislation, and the pre-trial requirement (article 43). See further Danilov, The Court of the Eurasian Economic Union, Gent 31 October 2014. 
the contrary, the election of a new government in Argentina has sparked hopes for a reconsideration of this project by the CMC. Accordingly, on 14 March 2016, the delegation of Paraguay at Parlasur submitted a note to the President of this body, inviting him to address again the CMC with a view to urge it to discuss the legislative proposal. Due to Uruguay's traditionally positive stance on this matter (in 1994 Uruguay had proposed the creation of a court of justice), ${ }^{86}$ there is hope that the presidency of this Member State at the CMC will also be favourable to the project. Despite the overwhelming number of arguments presented by officials and legal scholars, at present the only certainty is that the Member States will have the last word on this issue.

\section{BIBLIOGRAPHY}

ATEla, Vicente et al., "Las retenciones a las exportaciones ante el ordenamiento jurídico del Mercosur. La CSJN va al Tribunal Permanente de Revisión. Análisis desde el derecho constitucional, de la integración y del internacional económico", Anales de la Facultad de Ciencias Jurídicas y Sociales, año 7, núm. 7, 2010.

BARENTS, René, Directory of EU Case Law on the Preliminary Ruling Procedure, Alphen aan den Rijn, Kluwer Law International (ed.), 2009.

BellocCHIO, Lucía, "Resolución de Controversias en el Mercosur ¿Hacia una Corte de Justicia para el Bloque?”, Congreso de Derecho Público «Democracia y Derechos», in: http: / /www. derecho.uba.ar/institucional/deinteres / derecho-de-la-integracion-lucia-bellocchio.pdf (last visited on 13 September 2016)

BLOCKMANS, Steven et al., "Towards a Eurasian Economic Union: The Challenge of Integration and Unity”, CEPS Special Report, núm. 75, diciembre de 2012 .

86 On that occasion, Uruguay had submitted a draft document on the establishment of a court of justice, produced by the National Commission of Lawyers, which had started its work in 1992 with a seminary organised by the Ministry of Foreign Affairs of Uruguay, to which Pierre Pescatore (ECJ) and Fernando Uribe Restrepo (TJCAN) had been invited. 
Esta revista forma parte del acervo de la Biblioteca Jurídica Virtual del Instituto de Investigaciones Jurídicas de la UNAM

BOROVIKOv, Edward and DANILOW, Igor, "B2B: Balancing the Court of the Eurasian Economic Union”, in: The Moscow Times of 17 March 2015, in: http: / / www.themoscowtimes.com / article/b2b-balancing-the-court-of-the-eurasian-economic-union/517551.html (last visited on 2 June 2016).

Chediak GonzÁlez, Jorge and Benítez Rodríguez, Pablo, “Acerca de la competencia consultiva del Tribunal Permanente de Revisión del Mercosur y de la experiencia del poder judicial del Uruguay en la tramitación de opiniones consultivas", Revista de la Secretaría del Tribunal Permanente de Revisión, año 2, núm. 4, 2014.

DeluCA, Santiago, "El Mercosur necesita su Maastricht", Pensar en Derecho, Buenos Aires, año 1, núm. 1, 2012.

DraGNEVA, Rilka y WolczuK, Kataryna, "Eurasian Economic Integration: Institutions, Promises and Faultlines", in Davier Cadier (ed.), The Geopolitics of Eurasian Economic Integration, Special Report 19, LSE IDEAS.

Gazze, Patricio, "Desarrollo del derecho ambiental en el ámbito del Mercosur. El desafío a futuro que plantea el caso de las pasteras del Río Uruguay”, El Derecho, 2013, año LI, núm. 66.

HOUSE OF LORDS, European Union Committee, $12^{\text {th }}$ Report of Session 2006-07, "Funding the European Union - Report with Evidence".

ISPOLINOV, Alexei, "First Judgments of the Court of the Eurasian Economic Community: Reviewing Private Rights in a New Regional Agreement”, Legal Issues of Economic Integration, vol. 40, núm. 3, 2013.

KARLIUK, Maksim, "The Eurasian Economic Union: An EU-like legal order in the post-Soviet space?", WP BRP 53/LAW/2015 National Research University Higher School of Economics, 2016.

KLumPP, Marianne, Schiedsgerichtsbarkeit und Ständiges Revisionsgericht des Mercosur, Heidelberg 2013.

KüHN, Werner Miguel, "Reflexiones sobre una posible convergencia regional con la participación de la Comunidad Andina y el Mercosur. Lecciones de la experiencia integracionista europea”, Política Internacional, núm. 109, julio-septiembre de 2013.

LenaerTs, Koen et al., EU Procedural Law, Oxford, Oxford University Press (ed.), 2014.

LEPOUTRE, Naiké, "Le renvoi préjudiciel et l'instauration d'un dialogue des juges - Le cas de la Cour de justice de l'Union européenne et du juge administratif français", Jurisdoctoria, núm. 6, junio de 2011. 
Esta revista forma parte del acervo de la Biblioteca Jurídica Virtual del Instituto de Investigaciones Jurídicas de la UNAM

LOGAR, Ana Cristina, "Tribunal de Justicia para el Mercosur. Una decisión impostergable”, Revista de Relaciones Internacionales, vol. 6, núm. 12, 1997.

Martínez Puñal, Antonio, "El Protocolo de Olivos para la Solución de Controversias en el Mercosur: una reforma en clave continuista”, Anuario de Derecho Europeo, 2003, núm. 3.

Noll, Gregor, Negotiating Asylum.The EU Acquis, Extraterritorial Protection and the Common Market of Deflection, The Hague, Martinus Nijhoff Publishers (ed.), 2000.

Peña-PinOn, Mariana, "Une cour de justice pour le Mercosur? Vraiesfausses avancées vers une institutionnalisation renforcée", Revue Québécoise de Droit International, vol. 25, núm. 1, 2012.

PerotTi, Alejandro, "El proyecto de creación de la Corte de Justicia del Mercosur: estado de las negociaciones”, Foro de Derecho Mercantil, núm. 25, octubre-diciembre 2009.

, "Algunos desafíos que presenta la constitución de un Tribunal de Justicia Comunitario”, El Derecho, Universidad Católica Argentina (ed.), 2011.

PunTsCHER, Sonja/Mokre, Monika/Latzer, Michael, The State of Europe. Transformations of Statehood from a European Perspective, Campus Verlag, Frankfurt am Main 2004.

REY CARO, Ernesto, "Reforzamiento institucional del Mercosur: El Tribunal Permanente de Revisión”, Anuario Argentino de Derecho Internacional, vol. 13, 2004.

, "Crisis Institucional en el Mercosur. El Laudo No 1/12 del Tribunal Permanente de Revisión”, Revista de la Facultad, vol. 4, núm. 2, 2013.

Ruiz DÍAz LABRAnO, Roberto, "Mercosur, necesidad de un tribunal de carácter supranacional”, Azpilcueta, núm. 14, 1999.

SASAKI OTANI, María Ángela, "El sistema de sanciones por incumplimiento en el ámbito de la Comunidad Andina”, Anuario Mexicano de Derecho Internacional, México, vol. 12, 2012.

Salazar Grande, César Ernesto y Ulate Chacón, Enrique Napoleón, Manual de Derecho Comunitario Centroamericano, 2a. ed., San Salvador, 2013.

SCOTTI, Luciana and KLEIN VIEIRA, Luciane, "La creación de un tribunal de justicia: un paso ineludible para el fortalecimiento del Mercosur", in Scotti, "Balances y perspectivas a 20 años de la constitución del Mercosur", 2013, p. 151 . 